\title{
Synthesis and Antimicrobial Activity of Plant Based Silver Nanoparticles - A Review
}

\author{
Sneha S. Bandekar', S.S.Kerur ${ }^{2}$, Sheela Kiran Kore ${ }^{3}$ and Prasad G. Hegde ${ }^{4}$ \\ ${ }^{1}{ }^{4}$ Department of Chemical Engineering, KLE Dr. M.S.Shesagiri College \\ of Engineering \& Technology, Belagavi. Karnataka, India \\ ${ }^{2}$ Department of Chemistry, KLE Dr. M.S.Shesagiri College of Engineering \\ \& Technology, Belagavi. Karnataka, India \\ ${ }^{3}$ Department of Electronics and Communication Engineering, KLE Dr. M.S.Shesagiri \\ College of Engineering \& Technology, Belagavi. Karnataka, India
}

\section{ABSTRACT}

Nanotechnology is an exciting and influential world of manufacturing nanoparticles that find varied medicines, bacterial studies, wastewater treatment, and many more applications. This review paper aims to review the synthesis of silver nanoparticles from horticultural sources and evaluate special applications causing a considerable impact on the environment. Conventionally silver nanoparticles are produced by various chemical and physical processes. Biosynthesis of silver nanoparticles offers alternative methods, where plant extract can be used instead of harmful chemicals. Among various nanoparticles, silver nanoparticles possess unique antibacterial and antiviral properties make them superior to other nanoparticles. The green chemistry approach for synthesizing silver nanomaterials is environmentally friendly, benign, and gaining wide popularity. Enzymes, proteins, phytochemicals, phytochelatin, and vitamins are biomolecules found in plant extracts. In the process of biosynthesis of AgNPs, plant extracts act as good reducing, capping agents.. Biomolecules help reduce and stabilize the process of silver nanoparticles. The biomolecules enhance the yield process of biosynthesis of AGNP. This review highlights a summary of silver nanoparticle biosynthesis and their antibacterial activity. Silver nanoparticles is a multidisciplinary area that has gained focus from researchers of diverse areas from science, pharmaceuticals, agriculture, and materials engineering due to their morphologies and composition. Various physical and chemical techniques for synthesis include biological methods, chemical reduction, electron irradiation, gamma irradiation, laser ablation, microwave processing, and photochemical methods. The authors have attempted to compile the reported studies regarding silver nanoparticle synthesis from plants and their specific antibacterial properties. This paper reviews various synthesis techniques from plant materials and medical applications of silver nanoparticles. An attempt is made to present the current state and future silver nanoparticle applications in general and antibacterial treatments in particular.

KEY WORDS: MICROORGANISMS, PHYTOCHEMICALS, PLANT EXTRACT, REDUCING AGENTS, AND SILVER NANOPARTICLES.

\section{ARTICLE INFORMATION}

*Corresponding Author: sneha2bandekar@gmail.com

Received 15th Oct 2020 Accepted after revision 30th Dec 2020

Print ISSN: 0974-6455 Online ISSN: 2321-4007 CODEN: BBRCBA

Thomson Reuters ISI Web of Science Clarivate Analytics USA and Crossref Indexed Journal

\section{Clarivate
Analytics}

NAAS Journal Score 2020 (4.31)

A Society of Science and Nature Publication,

Bhopal India 2020. All rights reserved.

Online Contents Available at: http//www.bbrc.in/

Doi: $h$ ttp://dx.doi.org/10.21786/bbrc/13.13/17 


\section{INTRODUCTION}

Nanotechnology is a promising, emergent field with interest applications to scientists and technologists interested in manufacturing new materials at the nano scale. Nanotechnology deals with the synthesis and applications of nanoparticles in the particle size $<100$ $\mathrm{nm}$ as stated by (Khalil et al., 2014). For the last, so many years, it can be noticed that metal nanoparticles have created interest due to their novel characteristics concerning biological, chemical, and physical properties; hence this has proved the most active field for carrying the coveted research reported by (Safari and Zarnegar, 2014 ; Sahoo et al., 2007). Nanoparticles have typical properties related to size, surface area, and morphology, which has caused a significant interest in its antibacterial properties.

Nanoparticles find applications in pharmaceutical, energy, food, electronics, optoelectronics, catalysis, and photochemical applications. For more than 2000 years, silver has been known as a metal that exhibits good medical properties. Silver-based compounds find enormous applications as antimicrobial agents. Silver nanoparticles exhibit low toxicity towards animals, but these ions cause toxicity to microorganisms; therefore, numerous applications are explored in medicine as observed by (Galdiero et al., 2014). Metallic nanoparticles such as copper, silver, titanium, and zinc nanoparticles have been extensively used in medicine, agriculture, and bioengineering mentioned by the authors (Albertos et al., 2015; Nasrollahzadeh et al., 2016 ; Rostami et al., 2016). The plant based natural antibacterials in nano form will enhance applications, will be available in a concentrated form and improve utility in diverse fields. Nanomaterials have been confirmed and accepted as antibacterial agents which is highlighted by (Marin et al., 2015 ; Naddeo et al., 2015). Plant extracts and molds are known to be used by Greeks and Egyptians to treat patients. Louis Pasteur and J. F. Joubert are known to employ antibacterial sterilization procedures.

Silver nanoparticles reveal the distinctive property of a relatively large surface area, surface area to volume ratio leading to enhanced chemical activity and crystallographic surface structure was observed by (Vorobyova et al., 1999). The authors have developed a standard operating procedure for nanomaterial synthesis. The natural remediation procedures motivate the use of metal nanomaterials derived from plant biomolecules to reduce microbes harmful effects as per (Kapoor et al., 1999), findings. Research findings indicate the synthesis of novel metal nanoparticles like silver, gold employing various bacterial and fungal strains. The bacterial strain, Pseudomonas stutzeri from silver mines produces silver nanoparticles was reported in (Klaus et al., 1999). Silver nanomaterials are renowned for their antibacterial activity; however, they are used in nanomedicines, electronic chip devices, biomedical engineering, energy, and food processing. Hence silver nanoparticles are considered a very indispensable group of nanomaterials was experimentally studied by (Rauwel et al., 2015).

\section{Biosynthesis of silver nanoparticles}

Figure 1: Schematic diagram for the biosynthesis of silver nanoparticles

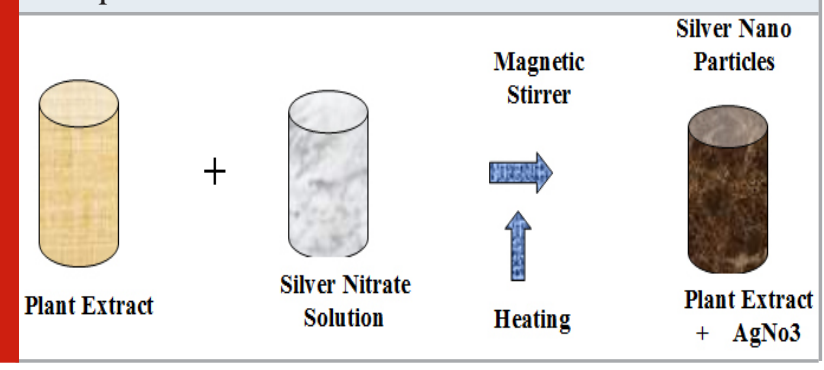

Research has evolved methods for extracellular Biosynthesis of AgNP's in size range of 5-50nm by actinomycete isolated from mangrove soil through an eco-friendly process by (Naddeoet al., 2015). Green synthesis from leaf extract of Azadirachta indicia is a simple, cost-effective, harmless, and energy-efficient procedure and yields stable silver nanomaterials. Azadirachta indica leaf extract acts as an outstanding reducing and capping agent was reported by (Ahmed et al., 2016). Similarly, silver nanomaterials are produced using different plant sources like Centella Asiatica, Citrus sinensis, Ocimum tenuiflorum, Solanum tricobatum, and Syzygium cuminiand were reported by (Logeswari et al., 2013). Silver nanoparticles were biosynthesized using the plant extract of Salvia spinosa, usually grown under vitro condition. The formation of synthesized AgNP's was confirmed by surface plasma resonance at $450 \mathrm{~nm}$ was clearly reported by (Pirtarighat et al., 2019). Degradation of methylene blue and characterization of synthesized nanomaterials are novel findings from this paper. The Biosynthesis of AgNP from Achyranthes Aspera plant extract is a promising method that does not involve harmful chemicals. Prepared silver nanoparticles were coated with chitosan (C.S.) biopolymer to guard against aggregation for better performance was reported by (Praveena and Kumar, 2014).

The researcher infers the synthesis of silver nanoparticles by eco-friendly green chemistry technique from a plant extract of endemic-medicinal plant Buddleja globose (Matico) as a promising methodology, cost-effective, rapid, and environmentally eco-friendly method for synthesizing metallic nanoparticles were meticulously planned and reported in the paper of (Carmona et al., 2017). The paper entitled in (Prakash et al., 2013), highlights the green synthesis of silver nanoparticles from Mimusops elengi L. at room temperature. Findings of the paper focuses on the biosynthesis of silver nanoparticles from plant Tribulus Terrestris L. fruit bodies were reported by (Gopinath et al., 2012) and concluded that the active phytochemical in plants was highly accountable for reducing silver ion $(\mathrm{Ag}+)$ to silver nanoparticles (Ago). (Dwivedi and Gopal, 2010) has reported about Ag and Au nanomaterial fast and straight forward green synthesis with an abhorrent weed, 
Table 1. Shows the biosynthesis of silver nanomaterials with different plant sources and their outcomes.

\begin{tabular}{|c|c|c|c|}
\hline Plant sources & Methods & Paper findings & Reference \\
\hline $\begin{array}{l}\text { Actinomycete from } \\
\text { mangrove soil }\end{array}$ & Extracellular synthesis & $\begin{array}{l}\text { Results show excellent } \\
\text { antimicrobial activity } \\
\text { towards multidrug resistance }\end{array}$ & (Narasimhaet al., 2013) \\
\hline $\begin{array}{l}\text { Mimusops elengi, } \\
\text { L. at room } \\
\text { temperature }\end{array}$ & Green synthesis & $\begin{array}{l}\text { Results show excellent antimicrobial } \\
\text { activity towards multidrug } \\
\text { resistance tested against } \\
\text { Escherichia coli }\end{array}$ & (Prakash et al 2013) \\
\hline $\begin{array}{l}\text { Tribulus Terrestris } \\
\text { L. fruit bodies }\end{array}$ & Biosynthesis & $\begin{array}{l}\text { Results show excellent antimicrobial } \\
\text { activity towards multidrug } \\
\text { resistance tested against bacteria }\end{array}$ & (Gopinath et al., 2012) \\
\hline $\begin{array}{l}\text { Azadirachta } \\
\text { indica }\end{array}$ & $\begin{array}{l}\text { Controllable } \\
\text { synthesis }\end{array}$ & $\begin{array}{l}\text { Results show excellent antimicrobial } \\
\text { activity towards multidrug resistance } \\
\text { tested against E. coli }\end{array}$ & (Ahmed et al.,2016) \\
\hline $\begin{array}{l}\text { Bark Ficus } \\
\text { benghalensis and } \\
\text { Azadirachta indica }\end{array}$ & Biosynthesis & $\begin{array}{l}\text { Results show very useful antibacterial } \\
\text { property against bacteria and also shows } \\
\text { antiproliferative activity against } \\
\text { MG-63 osteosarcoma with varied dosage }\end{array}$ & (Nayak et al., 2016) \\
\hline Ziziphora tenuior & Green synthesis & $\begin{array}{l}\text { This study explores the antioxidant } \\
\text { properties of these plants and then } \\
\text { synthesis the silver nanoparticles }\end{array}$ & $\begin{array}{c}\text { (Sadeghi and } \\
\text { Gholamhoseinpoor, 2015) }\end{array}$ \\
\hline $\begin{array}{l}\text { Citrus sinensis, } \\
\text { Solanum, tricobatum, } \\
\text { and Syzygium } \\
\text { cumini Centella }\end{array}$ & Biosynthesis & $\begin{array}{l}\text { This diffusion method have } \\
\text { efficient antimicrobial activity } \\
\text { against pathogenic bacteria }\end{array}$ & (Logeswariet al., 2015) \\
\hline Ocimum sanctum & Biosynthesis & $\begin{array}{l}\text { Shows adequate } \\
\text { robustness against } \\
\text { agglomeration }\end{array}$ & (Ahmad et al., 2010) \\
\hline
\end{tabular}

Chenopodium album, by a one-pot process. (Rashid et al., 2016) were highlighted synthesis of Silver nanoparticles using a plant extract of P. Dactylifera and tested against the bacteria. Synthesis of AgNP's from aqueous extract of Neem leaves (Azadirachta indica) was tested for antimicrobial activity and reported by (Verma and Mehata, 2016). (Jyoti et al., 2016) reported that silver nanoparticles were biosynthesized by green chemistry path using aqueous leaves extract of Urtica dioica and and tested against various bacterias. (Kumar et al., 2017), reported clearly on green synthesis of AgNP's from Andean blackberry fruit extracts and used in various biomedical and medicinal fields. Authors infer synthesis of biomolecules free from harmful chemicals gives novel phytochemistry. Silver nanoparticles synthesized from different Lantana Camara leaf extract quantify to estimate competent bactericidal action was practically reported in paper of (Albertos et al., 2015).

(Nayak et al., 2016), were carried out their work experimentally and reported that silver nanoparticles were synthesized using bark extracts of Ficus benghalensis and Azadirachta indica. The authors reveal that plant extract has biomolecules that can trim down silver metal ions $\mathrm{Ag}+$ to silver nanoparticles Ag0 by green synthesis. The plant extract of a varied range of Ziziphora tenuior
(Zt) was used to synthesize AgNP's silver. Sadeghi and Gholamhoseinpoor, 2015 were mentioned that, the study explores the antioxidant properties of plants and then biosynthesis of silver nanoparticles were carried out. The paper highlights a new biosynthesis path for silver nanoparticles (Ag-NPs) by aqueous extracts of Trachyspermum Ammi and Papaver somniferum. The authors, (Vijayaraghavan et al., 2012) studied the plant components thouroughly and concluded that these plants are act as reducing agents than the alkaloids present in the same plants.

(Logeswari et al., 2015) were observed and concluded that the biosynthesis of AgNP's from commercially accessible plant powders as Centella Asiatica, Citrus sinensis, Solanum tricobatum, and Syzygium cumini. (Kathiraven et al., 2015) reported in their study that the AgNP's were synthesized by different sources of plants such as Caulerpa racemosa, marine algae. (Pourmortazavi et al., 2015) reported that silver nanomaterials can be prepared by using seaweed extract with different concentration of silver nitrate solution at atmospheric conditions. The paper presents a synthesis of AgNP's from an aqueous extract of Eucalyptus oleosa. Colloidal AgNP's were prepared by using a silver nitrate solution. The study highlights the synthesis of silver nanomaterials from 
room dried stem and root of 0cimum sanctum extract. The authors (Ahmad et al., 2010) says that plants respond to produce phytochelatins or other metalchelating peptides.

III. Characterization techniques: The synthesized nanoparticles are tested using U.V. Spectrophotometer (UV-VIS), Fourier Transform-InfraRed spectroscopy (FTIR), and Transmission Electron Microscope (TEM) analysis. AgNP's show excellent antimicrobial activity towards multidrug resistance has been reported by (Narasimha et al., 2013). Synthesized silver nanoparticles are tested using FTIR, TEM, and U.V. Visible Spectrophotometer and Dynamic Light Scattering (DLS). Synthesized silver nanoparticles have shown excellent property towards antibacterial tests reported by (Ahmad et al., 2016). Results were analyzed using the U.V-Vis spectrophotometer; particle size of silver nanomaterials were calculated using the X-ray diffractometer (XRD) using the Debey Scherrer equation. An Atomic Force Microscope (AFM) was used to determine AgNP's structure, and SEM gives the morphology of synthesized silver nanomaterials were reported by (Logeswari et al., 2013). Synthesized AgNP's were analyzed by Field Emission Scanning Electron Microscope (FESEM), XRD, and FTIR was reported by (Pirtarighat et al., 2019).

\begin{tabular}{|c|c|c|c|}
\hline Plant part & $\begin{array}{l}\text { Characterization } \\
\text { Methods }\end{array}$ & $\begin{array}{l}\text { Size of } \\
\text { AgNP's }\end{array}$ & Reference \\
\hline Tribulus terrestris L. fruit bodies & $\begin{array}{l}\text { Surface Plasmon } \\
\text { Resonance }\end{array}$ & 460-540nm & (Dwivedi and Gopal,2010) \\
\hline Neem (Azadirachta indica) leaves & XRD & 20-30nm & (Jyoti et al., 2016) \\
\hline Andean blackberry fruit extracts & U.V-VIS & $435 \mathrm{~nm}$ & (Kumar et al., 2017) \\
\hline Andean blackberry fruit extracts & TEM & $12-50 \mathrm{~nm}$ & (Kumar et al., 2017) \\
\hline Ziziphora tenuior $(\mathrm{Zt})$ leaves & SEM \& TEM & 8-40nm & (Sadeghi and Gholamhoseinpoor, 2015] \\
\hline $\begin{array}{l}\text { Caulerpa racemosa, marine algae } \\
\text { (sea weed) }\end{array}$ & TEM & $5-25 \mathrm{~nm}$ & [Kathiraven et al., 2015) \\
\hline $\begin{array}{l}\text { Trachyspermum ammi and Papaver } \\
\text { somniferum aqu extract }\end{array}$ & TEM & $87-998 \mathrm{~nm}$ & (Vijayaraghavan et al., 2012) \\
\hline
\end{tabular}

Nanoparticles were characterized by U.V.-Vis Spectrophotometer, FTIR, TEM \& XRD, which confirmed the crystalline character of particles, and TEM gives the shape of the silver nanoparticles. (Praveena and Kumar, 2014) reported that synthesized CS-AgNPs were analyzed by the U.V spectrophotometer and FTIR spectroscopy. As reported by (Carmona et al., 2017) synthesized silver nanoparticles were characterized by U.V spectrophotometer to confirm the uniformity in size of nanoparticles TEM, FTIR, and X-Ray Photoelectron Spectroscopy were collectively used to determine the characteristics, oxidation states, and the functional groups of silver nanoparticles.

Energy dispersion X-ray (EDS) indicated the presence of $\mathrm{Ag}, \mathrm{C}, \mathrm{Cu}$, and $\mathrm{O}$, with a spherical shape, in the particle size distribution range of $16 \mathrm{~nm}$. Synthesized silver nanoparticles were characterized by using different techniques such as, FTIR is used to find out the identity of compounds which is liable for the reduction of $\mathrm{Ag}+$ ions and stabilization of AgNP's synthesized, U.V. Visible Spectrophotometer is used for confirmation of nanoparticles, The morphology of synthesized silver nanoparticles were analyzed by SEM technique, XRD was used to check crystalline nature of silver nanoparticles which is reported by (Prakash et al., 2013). (Gopinath et al., 2012) says that produced silver nanoparticles were analyzed using TEM, AFM, XRD, FTIR, and U.V. visible spectroscopy and confirmed.
On the other hand, (Dwivedi and Gopal, 2010) reported that synthesized $\mathrm{Ag}$ and $\mathrm{Au}$ nanoparticles and testing of activity with a U.V.-VIS spectrophotometer. The Surface Plasmon Resonance (SPR) of both synthesized AgNP's are found in size range of 460-540 nm. Factors, namely contact time, leaf extract quantities, metal concentrations, $\mathrm{pH}$, and temperature, are evaluated to know the effect on the synthesis of sliver and gold nanoparticles. Synthesized AgNP's were characterized by TEM, XRD, FTIR, and EDX.

The stability of produced AgNP's without stabilization agents was evaluated at different $\mathrm{pH}$ by a zeta potentiometer. (Rashid M. et al., 2016; Pirtarighat et al., 2019) reported that the characterization of silver nanomaterials by SEM to understand the morphology of nanoparticles and XRD to know the particle shape and elemental composition. (Verma and Mehata, 2016) reported that synthesized nanoparticles were characterized and analyzed by X-Ray Diffraction, SEM, FTIR, optical absorption, and photoluminescence (P.L.). These prepared nanoparticles reflect the minimum energy band at $400 \mathrm{~nm}$. The researcher evaluated the effect of extract concentrations, $\mathrm{pH}$, reactant ratio, temperature, and contact time of synthesized silver nanoparticles.

As reported in (Jyothi et al., 2016) UV-VIS spectroscopy confirms the formation of silver nanoparticles. XRD results infer synthesized silver nanoparticles are in size range of 20-30 nm and have an FCC crystal structure. 
FTIR enlightens about the functional groups of silver nanoparticles, Zeta-sizer and Zeta-potential show the potentiality of particles. SEM exhibits the morphology of the obtained silver nanoparticles. Energy dispersive $\mathrm{X}$-ray (EDX) spectroscopy gives elemental analysis, TEM, and selected area electron diffraction (SAED) to show the structure pattern of the material. As reported by (Kumar et al., 2017) the AgNP's UV-Vis spectra occur at $\lambda \max =435 \mathrm{~nm}$, TEM indicates the crystalline structure and spherical shaped particles in a size range of 12 to $50 \mathrm{~nm}$.

The XRD diffraction peaks at $38.04^{\circ}, 44.06^{\circ}, 64.34^{\circ}$, and $77.17^{\circ}$ confirmed the crystalline nature of AgNPs. FTIR Spectroscopy analysis identifies the functional groups responsible for the synthesis of the AgNPs. Ajitha et al., 2015 have been reported that various instrumental techniques were used to characterize silver nanoparticles. XRD and Selected Area Electron Diffraction (SAED) were used to confirm crystalline silver nanoparticles synthesis. In comparison, X-Ray Photoelectron Spectroscopy (XPS) analyses the confirmative formation of metallic AgNP's. Confirmation of colloidal AgNP's can be concluded from U.V.-Visible Spectrophotometer. FTIR confirms functional groups of silver nanoparticles. TEM shows the spherical size of AgNP's.

On the other hand, (Nayak et al., 2016) have reported that the synthesized silver nanoparticles could be preliminarily identified by color, which gives the formation of silver nanoparticles and is further validated by using UV-Visible spectroscopy. FESEM and AFM analyzed the structure of synthesized AgNP's. XRD patterns show the crystal structure of the obtained AgNP's. Synthesized AgNP's were tested and confirmation of silver nanoparticles were performed by X-Ray diffraction Spectrophotometer with high purity with a size of $38 \mathrm{~nm}$.

SEM and TEM, confirm the obtained silver nanoparticles are spherical in shape and size in the range of 8 to $40 \mathrm{~nm}$. FTIR spectroscopy exposed that obtained AgNP's have functionalized biomolecules with a varied amine, carbonyl, and $\mathrm{O}-\mathrm{H}$ and other stabilizing groups reported by (Sadeghi and Gholamhoseinpoor, 2015). (Vijayraghavan et al., 2012) reported that synthesis of silver nanoparticles with a spherical shape in the range of 3.2 to $7.6 \mu \mathrm{m}$ and also different shaped nanoparticles in the range of $87 \mathrm{~nm}$ to $998 \mathrm{~nm}$ from Trachyspermum Ammi. (Logeswari et al., 2013) have reported that synthesized silver nanoparticles were analyzed by UVVisible Spectrophotometer, which is used to confirm the formation of AgNP's and stability of AgNP's. The diameter of silver nanoparticles was calculated by Debey Scherrer equation of the XRD Pattern. AFM results show that irregular shapes of silver nanoparticles were 41 , 42, 52, and $53 \mathrm{~nm}$, corresponding to Citrus sinensis, Centella asiatica, Solanum tricobatum, and Syzygium cumini, respectively.

FTIR spectroscopy shows the presence of protein as the stabilizing agents near the silver nanoparticles. (Kathiraven et al., 2014) reported that the synthesized silver nanoparticles were characterized using U.V-Visible spectrometry, which revealed surface plasmon resonance at $413 \mathrm{~nm}$. FTIR gives promising functional groups. $\mathrm{OH}$ and amyl, which is accountable for the reduction and stabilization of AgNP's. XRD infers that particles with crystalline and face-centered cubic structure.TEM shows the silver nanoparticles' formation with a particle size of $5-25 \mathrm{~nm}$.

(Pourmortazavi et al., 2017) have carried out optimization studies on factors affecting AgNP's yield such as concentration of silver nitrate solution, concentrations of plant extract, temperature, and reaction time. Studies of these factors of different plant extract against the particle size of prepared AgNP's were validated. The contribution of different factors in controlling the particle size of silver particles was assessed by analysis of variance method (ANOVA).

The results show that synthesized silver nanoparticles need fine-tuning of controllable parameters to obtain particles with an average size $21 \mathrm{~nm}$. U.V. -Visible spectroscopy was used to confirm silver nanoparticles presence, whereas FTIR was used for the determination of functional groups. It was observed from (Ahmad et al., 2010) reported that synthesized silver nanomaterials are characterized by U.V Visible spectroscopy for the confirmation of silver nanomaterials. The crystal structure of AgNP's was analyzed by TEM, SAED, and XRD patterns. TEM shows that analyzed silver nanoparticles from a root having an average size of $10 \pm 2$ $\mathrm{nm}$ and stem had $5 \pm 1.5 \mathrm{~nm}$, respectively. Authors are reported various techniques for characterization; among those, a few are reported in Table. 2.

\section{Bacterial action of biosynthesized silver nanoparticles:} The AgNP's synthesized has efficient antimicrobial activity against pathogenic, gram-positive, and gramnegative bacteria reported by (Logeshwari et al., 2015). (Praveena and Kumar, 2014) have been reported that synthesized CS-AgNPs exhibited excellent antimicrobial activity when tested for E. coli and Staphylococcus aureus. Synthesized silver nanoparticles were tested for antibacterial activity was reported by (Prakash et al., 2013). The tests infer that synthesized nanomaterials are spherical in the range of $16 \mathrm{~nm}$ to $28 \mathrm{~nm}$ in size. Further, it was tested against different bacteria and reported by (Gopinath et al., 2012). Synthesized silver nanoparticles were tested against E. coli and K. Pneumoniae. The growth kinetics studies confirmed that 100\% potency for both the bacteria. It shows that silver nanoparticles rupture the cell membrane of bacteria and act as an excellent antibacterial agent. The developed method is a potential challenger in pharma products and medicines was reported by (Rashid et al., 2016).

(Verma and Mehata, 2016) were observed that the silver nanoparticle properties were improved with aging for upper temperature and alkalinity. The synthesized silver nanoparticles have better antimicrobial activities against Escherichia coli present in garden soil samples. These obtained results synthesized AgNP's could be 
used in assorted biomedical and nanotechnology. (Jyoti et al., 2016) practically observed that the synthesized AgNP's shows significant antibacterial activity against gram-positive and gram-negative bacteria. AgNP's with antibodies shows exceptional results than silver nanoparticles stand alone. This can be used as a medication for contagious diseases caused by bacteria. The synergistic function of silver nanoparticles is comparable to Amoxycillin against $S$. marcescens.

Hence, silver nanoparticles can help to improve the performance of antibiotics. (Kumar et al., 2017) were concluded that obtained silver nanoparticles show good antioxidant efficiency $(>78 \%, 0.1 \mathrm{mM})$ against 1,1-diphenyl-2-picrylhydrazyl. The synthesis process is an environmental ecofriendly and promising aspirant for biomedical applications.These particles exhibit antibacterial activity against bacteria. (Nayak et al., 2016) experimentally prooved thhat synthesized AgNP's show very effective antibacterial and antiproliferative action against MG-63 osteosarcoma sect with varied dosage; hence, it is a valuable restorative mediator against bacteria osteosarcoma and microbes.
(Logeswari et al., 2013) highlighted that synthesized silver nanoparticles were tested against Pseudomonas aeruginosa, and it is observed that the diffusion method has efficient antimicrobial activity against pathogenic bacteria. (Kathiraven et al., 2015) have been reported that the obtained AgNP's were tested against human pathogens, which show the best antibacterial activity, and could be applicable for industrial and therapeutic needs. As per (Ahmad et al., 2010), it was notified that due to phytochemical properties, synthesized silver nanoparticles provide practical robustness against agglomeration. Table 3 represented plant sources utilized during the synthesis of AgNP's and tested against different bacteria.

V. Mechanism of biosynthesis of silver nanoparticles

$$
\begin{gathered}
\mathrm{AgNO}_{3} \rightarrow \mathrm{Ag}++\mathrm{NO}_{3}^{-} \\
\mathrm{AgNO}_{3}+\text { plant extract } \rightarrow \mathrm{AgO}+\mathrm{NO}_{2}^{-}
\end{gathered}
$$

(Nitrate reductase confirms the presence of silver nanoparticles)

Table 3. Bio synthesized AgNP's tested against microorganisms

\begin{tabular}{|l|c|c|}
\hline Plant extract & Test Bacteria & Reference \\
\hline $\begin{array}{l}\text { Centellaasiatica, Citrus sinensis, } \\
\text { Ocimum tenuiflorum, Solanum } \\
\text { tricobatum, and Syzygium cumini }\end{array}$ & both gram +ve, gram -ve bacteria & (Logeswari et al.,2015) \\
\hline Achyranthes aspera & E. coli and Staphylococcus aureus & (Praveena and Kumar,2014) \\
\hline P. Dactylifera & E. coli and K. Pneumoniae. & (Rashid et al.m 2016) \\
\hline Neem (Azadirachta indica) & Escherichia coli & (Verma and Mehata, 2016) \\
\hline Urtica dioica & S. marcescens & (Jyoti et al., 2016) \\
\hline $\begin{array}{l}\text { Ficus benghalensis and } \\
\text { Azadirachta indica }\end{array}$ & MG-63 osteosarcoma & (Logeswari et al., 2013) \\
\hline $\begin{array}{l}\text { Plant powders as Centella asiatica, } \\
\text { Citrus sinensis, Solanum } \\
\text { tricobatum and Syzygium cumini. }\end{array}$ & Pathogenic bacteria & \\
\hline
\end{tabular}

Figure 2: Mechanism of biosynthesis of silver nanoparticl (Natsuki and Abe, 2011).

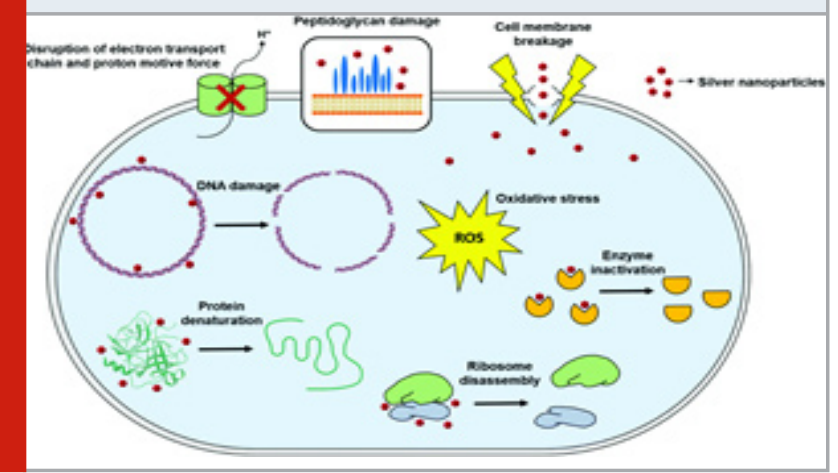

Singh et al., 2015 exclusively reported that the plant extract may be effectively used as a reducing agent; therefore, silver $\mathrm{Ag}^{+}$ions are derived from the plant extract biomolecules. As shown in reactions, silver ions can be produced using nitrate reductant from plant extract. Biomolecules present in plants are proteins, enzymes, and vitamins; hence enzyme converts these $\mathrm{NO}_{3}$ to $\mathrm{NO}_{2}$. It is suggested that the reduction to metallic silver $\left(\mathrm{Ag}^{0}\right)$ is due to the transferred electron to the silver ion $\left(\mathrm{Ag}^{+}\right)$.

Microorganism from metals and metalloids develop a definite inherent and biochemical metal fighting mechanism that includes extracellular precipitation, intracellular deposition, solubility variation, toxicity level, cell membrane breakage, disruption of the electron, DNA damaging, oxidative stress (ROS), enzyme inactivation, and protein damage are elucidated in Figure 2. Silver ions have powerful resistance against different bacteria. This can be shown by the reduction of metal 
ions as AgNP's. The mechanism involved in the synthesis and antibacterial activity is not implicit property, but many hypotheses have been proposed to reveal the bacterial responsibility in the synthesis of AgNP's.

(Roy et al., 2019) studies revealed that silver nanoparticles have significant cell disruption, bacteria-fighting, cell-damaging property, and alone or combined with different antibiotic medicines that have been proved against various bacterial infections, as mentioned in Table.1. Research has been carried out to understand the mechanism related to cell wall damage, intracellular penetration, and oxidative stress. Figure .2 represents the pictorial presentation of the various mechanism of silver nanomaterials.

(Natsuki and Abe, 2011) particularly mentioned that nanotechnology is an emerging area with numerous uses in fields like printed, electronic circuits, and consumer electronics. Colloidal silver Nanoparticles have excellent optical, physical, and chemical properties along with high electroconductivity. Colloidal silver nanoparticles have diameters as low as 1 to $10 \mathrm{~nm}$ making them suitable for electronics printing integrated circuit boards. The injecting technology is used to print delicate and complicated electronic circuits because of the uniform minute silver metal nanoparticles in ink. (Allsopp et al., 2007) have been reported that nanosilver particles have found broad uses in high-end consumer electronics like Refrigerators, Vacuum cleaners, optical mouse, and mobile phones. In Daewoo refrigerators, silver nanoparticles are mixed with plastic resin and used in the refrigerators to suppress bacteria and odor growth. In the Daewoo Vacuum cleaner, the silver nanoparticle is used to coat the dust collecting drum where germs and bacteria can be eliminated. IOGEAR developed a germ-free wireless laser mouse coated with a compound of titanium dioxide and silver nanoparticles.

\section{CONCLUSION}

Based on the reviewed discussions, it is observed that biosynthesis of silver nanomaterials may serve as the best antibacterial compounds in biomedical nanotechnology and multidrug resistance in pharmaceutical fields. The review paper highlights more about Biosynthesis, characterization, and antibacterial activity of AgNP's. The cuurent research from cited literature mainly focuses on biosynthesis of AgNP's using different parts of plant, and applicability as excellent reducing or capping agent. Understanding the role of isolated biomolecules is very difficult from biosynthesis chemistry. Based on the discussions, it can be concluded that an optimization study may give more transparency and a better understanding of green chemistry. Characterization techniques focused on this review are XRD, TEM, SAED, FTIR, ANOVA, XPS, AFM, and U.V.-Visible spectrophotometer. Different techniques were used to get different analyses in terms of particle size, morphology, crystallinity, functional groups, and confirm the formation of silver nanoparticles. Overall, Bio synthesized silver nanoparticles show excellent properties against the different varied bacteria, as shown in Table. 1 and Table 3.

Most importantly, different plant sources can be utilized to synthesize silver nanoparticles, these are used as good reducing agents, and no harmful chemicals were used. Therefore Bio synthesized AgNP's are entirely free from chemicals. These developed methods are more economical and cost-effective, environmentally ecofriendly, and enhance the synthesis rates, quality, and antibacterial activity. The specificity of antibacterials is a highly desired property during the treatment of bacterial infections without affecting the natural existing flora. In the future, the Green chemistry process of silver nanomaterials may act as the best approach.

\section{ACKNOWLEDGEMENTS}

The authors deem it a privilege to thank Dr. Basavaraj G. Katageri, Principal of KLE Dr. M. S. S. College of Engineering and Technology, Belagavi and Vision Group Science \& Technology (VGST), Bengaluru and Govt.of India for funding and extending support to conduct of experimental work and also for the motivation.

\section{REFERENCES}

Ahmad, N., Sharma, S., Alam, M. K., Singh, V. N., Shamsi, S. F., Mehta, B. R., \&t Fatma, A. (2010). Rapid synthesis of silver nanoparticles using dried medicinal plant of basil. Colloids and Surfaces B: Biointerfaces, 81(1), 81-86.

Ahmed, S., Saifullah, Ahmad, M., Swami, B. L., \& Ikram, S. (2016). Green synthesis of silver nanoparticles using Azadirachta indica aqueous leaf extract. Journal of radiation research and applied sciences, 9(1), 1-7.

Ajitha, B., Reddy, Y. A. K., \& Reddy, P. S. (2015). Green synthesis and characterization of silver nanoparticles using Lantana camara leaf extract. Materials science and engineering: C, 49, 373-381.

Albertos, P., Romero-Puertas, M. C., Tatematsu, K., Mateos, I., Sánchez-Vicente, I., Nambara, E., \&t Lorenzo, 0. (2015). S-nitrosylation triggers ABI5 degradation to promote seed germination and seedling growth. Nature Communications, 6(1), 1-10.

Albrecht, M.A., Evans, C.W., Raston, C.L., 2006. Green chemistry and the health implications of nanoparticles. Green Chem. 8, 417- 432.

Allsopp, M., Walters, A., \& Santillo, D. (2007). Nanotechnologies and nanomaterials in electrical and electronic goods: A review of uses and health concerns. Greenpeace Research Laboratories, London.

Carmona, E. R., Benito, N., Plaza, T., \&t Recio-Sánchez, G. (2017). Green synthesis of silver nanoparticles by using leaf extracts from the endemic Buddleja globosa hope. Green Chemistry Letters and Reviews, 10(4), 250-256. Dwivedi, A. D., \&t Gopal, K. (2010). Biosynthesis of silver and gold nanoparticles using Chenopodium album leaf extract. Colloids and Surfaces A: Physicochemical and Engineering Aspects, 369(1-3), 27-33. 
Firdhouse, M. J., \&t Lalitha, P. (2015). Biosynthesis of silver nanoparticles and its applications. Journal of Nanotechnology, 2015.

Galdiero, S., Falanga, A., Cantisani, M., Ingle, A., Galdiero, M., \& Rai, M. (2014). Silver nanoparticles as novel antibacterial and antiviral agents. In Handbook of nanobiomedical research: Fundamentals, Applications and Recent Developments: Volume 1. Materials for Nanomedicine (pp. 565-594).

Gopinath, V., MubarakAli, D., Priyadarshini, S., Priyadharsshini, N. M., Thajuddin, N., \&t Velusamy, P. (2012). Biosynthesis of silver nanoparticles from Tribulus terrestris and its antimicrobial activity: a novel biological approach. Colloids and Surfaces B: Biointerfaces, 96, 69-74.

Jyoti, K., Baunthiyal, M., \&t Singh, A. (2016). Characterization of silver nanoparticles synthesized using Urtica dioica Linn. leaves and their synergistic effects with antibiotics. Journal of Radiation Research and Applied Sciences, 9(3), 217-227.

Kapoor, A., Viraraghavan, T., \& Cullimore, D.R. (1999). Removal of heavy metals using the fungus Aspergillus niger. Bioresource Technology, 70: 95-104.

Kathiraven, T., Sundaramanickam, A., Shanmugam, N., \&t Balasubramanian, T. (2015). Green synthesis of silver nanoparticles using marine algae Caulerpa racemosa and their antibacterial activity against some human pathogens. Applied Nanoscience, 5(4), 499-504.

Khalil, M. M., Ismail, E. H., El-Baghdady, K. Z., Et Mohamed, D. (2014). Green synthesis of silver nanoparticles using olive leaf extract and its antibacterial activity. Arabian Journal of Chemistry, 7(6), 11311139.

Klaus, T., Joerger, R., Olsson, E., \&t Granqvist, C. G. (1999). Silver-based crystalline nanoparticles, microbially fabricated. Proc. Nat. Acad. Sci. USA, 96, 13611-13614

Kumar, B., Smita, K., Cumbal, L., \&t Debut, A. (2017). Green synthesis of silver nanoparticles using Andean blackberry fruit extract. Saudi journal of biological sciences, 24(1), 45-50.

Logeswari, P., Silambarasan, S., \&t Abraham, J. (2013). Ecofriendly synthesis of silver nanoparticles from commercially available plant powders and their antibacterial properties. Scientia Iranica, 20(3), 10491054.

Logeswari, P., Silambarasan, S., \&t Abraham, J. (2015). Synthesis of silver nanoparticles using plants extract and analysis of their antimicrobial property. Journal of Saudi Chemical Society, 19(3), 311-317.

Marin, S., Mihail Vlasceanu, G., Elena Tiplea, R., Raluca Bucur, I., Lemnaru, M., Minodora Marin, M., \&t Mihai Grumezescu, A. (2015). Applications and toxicity of silver nanoparticles: a recent review. Current topics in medicinal chemistry, 15(16), 1596-1604.

Naddeo, J. J., Ratti, M., O’Malley, S. M., Griepenburg, J. C., Bubb, D. M., \&t Klein, E. A. (2015). Antibacterial properties of nanoparticles: a comparative review of chemically synthesized and laser-generated particles. Advanced Science, Engineering and Medicine, 7(12), 1044-1057.

Narasimha, G., Alzohairy, M., Khadri, H., \& Mallikarjuna, K. (2013). Extracellular synthesis, characterization and antibacterial activity of Silver nanoparticles by Actinomycetes isolative.

Nasrollahzadeh, M., Atarod, M., Jaleh, B., At Gandomirouzbahani, M. (2016). In situ green synthesis of Ag nanoparticles on graphene oxide/TiO2 nanocomposite and their catalytic activity for the reduction of 4-nitrophenol, congo red and methylene blue. Ceramics International, 42(7), 8587-8596.

Natsuki, J., \& Abe, T. (2011). Synthesis of pure colloidal silver nanoparticles with high electroconductivity for printed electronic circuits: The effect of amines on their formation in aqueous media. Journal of colloid and interface science, 359(1), 19-23.

Nayak, D., Ashe, S., Rauta, P. R., Kumari, M., \&t Nayak, B. (2016). Bark extract mediated green synthesis of silver nanoparticles: evaluation of antimicrobial activity and antiproliferative response against osteosarcoma. Materials Science and Engineering: C, 58, 44-52.

Pirtarighat, S., Ghannadnia, M., \&t Baghshahi, S. (2019). Green synthesis of silver nanoparticles using the plant extract of Salvia spinosa grown in vitro and their antibacterial activity assessment. Journal of Nanostructure in Chemistry, 9(1), 1-9.

Pourmortazavi, S. M., Taghdiri, M., Makari, V., \&t Rahimi-Nasrabadi, M. (2015). Procedure optimization for green synthesis of silver nanoparticles by aqueous extract of Eucalyptus oleosa. Spectrochimica Acta Part A: Molecular and Biomolecular Spectroscopy, 136, 1249-1254.

Prakash, P., Gnanaprakasam, P., Emmanuel, R., Arokiyaraj, S., \& Saravanan, M. (2013). Green synthesis of silver nanoparticles from leaf extract of Mimusops elengi, Linn. for enhanced antibacterial activity against multi drug resistant clinical isolates. Colloids and Surfaces B: Biointerfaces, 108, 255-259.

Praveena, V. D., \& Kumar, K. V. (2014). Green synthesis of silver nanoparticles from Achyranthes aspera plant extract in chitosan matrix and evaluation of their antimicrobial activities. Indian Journal of Advances in Chemical Science, 2(3), 171-177.

Rashid, M. I., Mujawar, L. H., Rehan, Z. A., Qari, H., Zeb, J., Almeelbi, T., \& Ismail, I. M. (2016). One-step synthesis of silver nanoparticles using Phoenix dactylifera leaves extract and their enhanced bactericidal activity. Journal of Molecular Liquids, 223, 1114-1122.

Rauwel, P., Küünal, S., Ferdov, S., \&t Rauwel, E. (2015). A review on the green synthesis of silver nanoparticles and their morphologies studied via TEM. Advances in Materials Science and Engineering, 2015.

Rostami-Vartooni, A., Nasrollahzadeh, M., \&t Alizadeh, M. (2016). Green synthesis of perlite supported silver 
nanoparticles using Hamamelis virginiana leaf extract and investigation of its catalytic activity for the reduction of 4-nitrophenol and Congo red. Journal of Alloys and Compounds, 680, 309-314.

Roy, A., Bulut, O., Some, S., Mandal, A. K., \&t Yilmaz, M. D. (2019). Green synthesis of silver nanoparticles: biomolecule-nanoparticle organizations targeting antimicrobial activity. RSC advances, 9(5), 26732702.

S.A. Vorobyova, A.I Lesnikovich, N.S Sobal. (1999) Preparation of silver nanoparticlesby interphase reduction, Colloids and Surfaces A: Physicochemical and Engineering Aspects, 152, 375-379.

Sadeghi, B., \&t Gholamhoseinpoor, F. (2015). A study on the stability and green synthesis of silver nanoparticles using Ziziphora tenuior (Zt) extract at room temperature. Spectrochimica Acta Part A: Molecular and Biomolecular Spectroscopy, 134, 310-315.

Safari J, Zarnegar Z (2014) Advanced drug delivery systems: Nanotechnology of health design A review. J
Saudi Chem Soc 18: 85- 99.

Sahoo SK, Parveen SPJ (2007) The present and future of nanotechnology in human health care. Nanomedicine 3: 20-31.

Siddiqi, K. S., Husen, A., \&t Rao, R. A. (2018). A review on biosynthesis of silver nanoparticles and their biocidal properties. Journal of nanobiotechnology, 16(1), 14.

Singh, R., Shedbalkar, U. U., Wadhwani, S. A., \&t Chopade, B. A. (2015). Bacteriagenic silver nanoparticles: synthesis, mechanism, and applications. Applied microbiology and biotechnology, 99(11), 4579-4593.

Verma, A., \&t Mehata, M. S. (2016). Controllable synthesis of silver nanoparticles using Neem leaves and their antimicrobial activity. Journal of radiation Research and applied sciences, 9(1), 109-115.

Vijayaraghavan, K., Nalini, S. K., Prakash, N. U., \&t Madhankumar, D. (2012). One step green synthesis of silver nano/microparticles using extracts of Trachyspermum ammi and Papaver somniferum. Colloids and Surfaces B: Biointerfaces, 94, 114-117. 